\title{
The Unique Vulnerabilities of Entrepreneurial Ventures to Misconduct
}

\author{
Donald Palmer \\ University of California, Davis \\ Tim Weiss \\ Imperial College London \\ February 9, 2022 \\ (Forthcoming in Research in Sociology of Organizations)
}

\begin{abstract}
Entrepreneurs and their ventures are often portrayed as unambiguously positive forces in society. Specifically, high technology and equity-funded startups are heralded for their innovative products and services that are believed to alter the economic, social, and even political fabric of life in advantageous ways. This chapter draws on established theory on the causes of misconduct in and by organizations to elaborate the factors that can give rise to misconduct in entrepreneurial ventures, illustrating our arguments with case material on both widely known and less well-known instances of entrepreneurial misconduct. In venturing into the dark side of entrepreneurship, we hope to contribute to theory on entrepreneurship and organizational misconduct, augment entrepreneurship pedagogy, and offer ideas and examples that can enhance entrepreneurs' awareness of their susceptibility to wrongdoing.
\end{abstract}

\section{Introduction}

Entrepreneurial ventures and their founders have assumed critical roles in capitalist societies. These ventures, also known as "startups," have spearheaded technological innovation, generated millions of jobs, and created trillions of dollars in stockholder value; in some instances, evolving to dominate the industries in which they are situated. Successful founders have amassed great wealth; in some cases, even acquiring celebrity status. Indeed, entrepreneurship is seen as an important way, in some eyes the most effective way, to address a vast array of social problems (c.f., Bruton, Ketchen, and Ireland 2013; Jones et. al., 2016; Zhao and Wry 2016; but see Acs et. al. 2016).

Consequently, startups and their founders have attracted the attention and imagination of academic researchers, college, secondary, and even grammar school educators, journalists, and the public at large. By in large, these audiences, as well as members of the general public (Gamez-Djokic, Kouchaki, and Waytz 2021), tend to view startups as more virtuous than established companies. ${ }^{1}$

Yet, startups and their founders' have suffered dents to their images over the past decade. A good number of startups have been accused of committing a range of unsavory behaviors. Elizabeth Holmes founded Theranos to develop a home blood testing machine that could conduct over one hundred tests on a single drop of blood, sparing needlephobic patients the ordeal of standard blood draws. But in 2015 suspicions arose about the firm's showcase technology, the Edison. Later, with the aid of whistleblowers, the technology was determined to be entirely fictious, in the parlance of the industry "vaporware," and Holmes was indicted for conspiracy and wire fraud (Carreyrou, 2018).

\footnotetext{
${ }^{1}$ Gamez-Djokic, Kouchaki, and Waytz (2021) conducted laboratory experiments in which subjects were found not only to view startups as more virtuous than established firms, but also more inclined to give startups the "benefit of the doubt" when they are associated with transgressive behaviors.
} 
Similarly, Elon Musk founded Tesla to manufacture an affordable electrical vehicle that would spearhead the development of environmentally sustainable transport in the US and abroad. But in 2018 he faced fraud charges brought by the U.S. Securities and Exchange Commission (SEC) over a tweet in which he falsely claimed his intention to delist the venture from the NASDAQ stock exchange, producing an immediate jump in the firm's share price (U.S. Securities and Exchange Commission, 2018). Concerningly, these are not isolated cases. Other high-profile startups such as WeWork and many less wellknown ventures such as Ubiome, Just Mayo, Nikola and others that we will discuss here have similarly been plagued by misconduct.

We draw on existing scholarship on the causes of misconduct in and by organizations to develop a preliminary analysis of misconduct in entrepreneurial ventures. A key insight of misconduct research is that wrongdoing is a normal phenomenon, in that it is prevalent and a product of organizational structures and processes that are inherent in formal organization (Palmer 2013). While the urge is strong to consider entrepreneurial misconduct an abnormal phenomenon, casting firms such as Theranos as outliers, we argue that misconduct in and by entrepreneurial ventures also is normal; that is, prevalent and a function of structures and processes inherent in entrepreneurship. As such, it deserves scholarly and practitioner attention.

We pursue three objectives in this chapter. First, we aspire to advance theory on entrepreneurship and on misconduct in and by organizations. Existing theories on entrepreneurship largely focuses on its positive aspects, concerned first-and-foremost with venture performance and success. We show how distinctive features of entrepreneurial ventures constitute vulnerabilities to misconduct. Existing theory on organizational wrongdoing focuses on large, established, professionally managed enterprises. We extend this theory into the domain of small, nascent, and founder managed ventures. Second, we strive to provide theoretical arguments and illustrate them with real world examples derived from journalistic accounts that can be used to expand the scope of pedagogy which to date has focused primarily on individual-level ethics and morality (Byers 2020; Shepherd, Patzelt, and Barron 2012; Shepherd 2019). Third, we endeavor to offer entrepreneurs insights that can help them stay on the right side of the line separating right from wrong.

This chapter proceeds as follows. First, we delineate the type of entrepreneurial ventures and misconduct on which we focus. Second, we elaborate known causes of misconduct in and by organizations, indicate how these causes manifest uniquely in entrepreneurial ventures, and provide examples of contemporary cases of entrepreneurial misconduct that illustrate our arguments. Finally, we summarize our main arguments, indicate their shortcomings, and offer suggestions for future research.

\section{Entrepreneurial Ventures and Misconduct}

\section{The Entrepreneurial Ventures on Which We Focus}

We focus on a subset of entrepreneurial ventures that are: 1) nascent, less than 10 years old at the time of misconduct, 2) primarily owned and controlled by their founders, who typically occupy the positions of chief executive officer and chairperson of the board of directors, 3) for-profit enterprises, although they may generate no revenue or operate at a loss, 4) risk-capital financed, with the objective of "going public" or becoming acquired, 
and 5) innovative in regards to the technologies they commercialize or the business models they adopt (Hsu 2008; Beckman, Eisenhardt, Meyer and Rajagopalan 2012). We focus on this subset of entrepreneurial ventures because it is the subset of ventures upon which scholars, educators, commentators, and the public focus most of their attention (Aldrich 2019). ${ }^{2}$

\section{The Misconduct in and by Organizations on Which We Focus}

We primarily focus on behavior that provokes formally constituted social control agents to investigate, indict, convict, and punish organizations or their participants. Such behaviors include wire fraud, scientific fraud, data fraud, performance and product misrepresentation, sexual harassment and assault, wage theft, and anti-competitive practices, among others. Formally constituted social control agents are organizations that are established for the purpose of policing organizational and organizational participant behavior and are recognized by the organizations and organizational participants they police as legitimate (albeit not always fair) adjudicators of their innocence or guilt. These organizations include professional associations, such as the American Institute of Certified Public Accountants, governmental bodies, such as the Securities and Exchange Commission, and law enforcement agencies, such as the United States Justice Department (Greve, Palmer, and Pozner 2010; Palmer 2013).

Focusing on behaviors that provoke reactions from formally constituted social control agents has advantages, the most important of which is that it renders the identification of misconduct an empirical exercise. Consequently, it frees us from the necessity of engaging in repeated theoretical or philosophical discussion about whether specific behaviors do or do not constitute wrongdoing. Most of the startups discussed in this chapter engaged in misconduct as defined in the above respect. But limiting our focus to behavior that provokes response from formally constituted social control agents has three significant disadvantages when studying misconduct in and by entrepreneurial ventures.

First, entrepreneurial ventures typically have short life spans and thus often do not survive long enough for any objectionable behavior they or their members perpetrate to come to the attention of formally constituted social control agents. For example, Planswell was founded in 2016 to offer online financial planning services. But in 2019, on the verge of securing a $\$ 20$ million risk capital investment, the Canadian fintech startup became the subject of a former employee's highly publicized sexual harassment allegations. The allegations led to investors' divestment and the firm's demise, even though the allegations were never litigated (Soltys 2019). Similarly, the promising Chinese autonomous vehicle startup Roadstar.ai collapsed following an investor revolt in the wake of misconduct allegations leveled first against the venture's Chief Scientist and later against its Chief Strategy Officer and CEO, without a formal investigation of any government agency (Nan 2019).

\footnotetext{
${ }^{2}$ We do not focus on ventures that have been the locus of high-profile misconduct, but only possess some of the above characteristics. For example, we do not focus on established, management controlled, bankfinanced, high-tech firms such as Hewlett Packard, which was the subject of a high profile "pretexting" scandal. Similarly, we do not focus on founder controlled, high technology firms that were risk capital financed, but have aged and grown to become established firms that dominate their industries such as Amazon, Google, and Facebook, each of which has been the locus of its own high-profile scandal.
} 
Second, startups are private entities and thus are largely exempted from the scrutiny to which public organizations are subjected. For example, Adam Neumann founded WeWork in 2010 to develop communal workspaces for firms that could not afford their own, independent rental spaces. Neumann engaged in excessive spending, self-dealing, and misrepresentation of the venture's performance for much of its early life. But his behavior only came to the attention of social control agents in 2019 when the venture filed documents in advance of its bid to go public (Eavis and de la Merced, 2019; Stoller 2019). Entrepreneurial ventures' insulation from scrutiny is bolstered by their recent tendency to stay private longer, pursuing additional rounds of Series D, E and F investments (Davis 2016, Joint Venure 2020).

Third, startups often inadvertently or intentionally occupy legal grey zones, gaps in the terrain patrolled by formally constituted social control agents. For example, Robert Boback founded Triversa in 2004 to meet the security needs of firms that experienced increasingly frequent data breaches and leaks. Boback published breached and leaked data on the "Deep Web" or "Dark Net" and then contacted the data owners to offer his venture's risk management services; sometimes exaggerating potential clients' risk and sometimes subtly threatening to spread the data to a wider audience if the companies did not engage Triversa's services. While the Federal Trade Commission (FTC) has long policed this exploitative marketing strategy, known as "fear, uncertainty, and doubt" (FUD), in non-internet businesses, it had little capacity and authority to police the strategy in the digital marketplace. As a result, the FTC not only failed to investigate Triversa's use of FUD but became an unwitting accomplice of the firm's misconduct. While the Justice Department eventually opened a criminal investigation of Boback, it ultimately dropped its inquiry, partly because Trivera's marketing practices did not clearly violate existing law (Khatchadourian 2019).

For these three reasons, we expand our primary focus to include behavior that provokes extensive negative media coverage of the type associated with scandals (Graffin et al. 2015). In most cases, such behavior would provoke a reaction from formally constituted social control agents if they knew of the behavior or if they had the time and attention to develop programs to address it. $^{3}$

\section{Eight Theorized Causes of Organizational Misconduct}

\section{Performance Strain}

Misconduct in and by organizations often is attributed to performance strain. Organizational actors experience strain when they possess a strong desire to achieve an objective but are unable to achieve it through legitimate means. For this reason, performance strain is sometimes called "blocked aspirations." When organizational actors experience strain, they tend to use illegitimate means to pursue their objectives. Scholars have invoked this theory to explain misconduct at the organizational (Staw and Szwajkowski 1975; Simpson 1986; McKendall and Wagner 1997) and the individual levels of analysis (Palmer and Yenkey 2015). Journalists and commentators frequently

\footnotetext{
${ }^{3}$ We believe that ours is the first attempt to elaborate the causes of broadly defined misconduct in high-tech equity funded startups. We note, though, that Scheaf and Wood (2001) recently developed a framework for understanding a narrower range of misconduct (fraud) within a broader category of entrepreneurial ventures (all new firms, as well as established firms engaged in innovative activities such as the creation of new products and services and entry into new markets).
} 
invoke strain theory to explain specific instances of misconduct (Gumbel, 2004; Timmons and Wassener 2009).

We think entrepreneurs are particularly likely to experience performance strain for two reasons. First, they possess a particularly strong desire to achieve their business objectives. Entrepreneurs are often characterized as possessing extraordinary passion for and optimism about achieving their objectives (Cardon, Wincent, Singh, and Drnovsek 2009; Amore, Garofalo, Martin-Sanchez 2020), partly because they view their ventures as expressions and extensions of their personal identities (Powell and Baker 2014; Fauchart and Gruber 2011). For example, Elizabeth Holmes founded Theranos to develop a way for people like herself, who possessed a deathly fear of needles, to obtain crucial diagnostic tests without subjecting themselves to standard blood draws (Carreyrou 2018). Similarly, Adam Neumann founded WeWork to advance his unique version of new age philosophy (Chozick 2019).

Further, entrepreneurs are typically advised to self-invest and show "skin in the game" by resourcing their early operations partly with their own investments (i.e., private savings, debt and time) and partly from close ties in their social networks (i.e., financial and human resources from friends and friends of friends) (Aldrich \& Ruef, 2006). If entrepreneurs invest the bulk of their savings and/or incur massive debt to launch their ventures, they may come to equate venture failure with personal financial ruin. Further, while socially embedded and affective relationships may be conducive to attracting critical resources early on, leading to venture growth (Huang and Knight 2017), they also may lock entrepreneurs into consequential relationships that make them reluctant to disappoint those around them. In short, for entrepreneurs, failure may not be an option.

Second, entrepreneurs are particularly likely to struggle to achieve their objectives. The founders of the enterprises upon which we focus tend to operate under conditions of extreme uncertainty, entering or creating new industries, developing new technologies, in the absence of organizing blueprints. Their difficulties are in part compounded by investors' exponential growth, so called blitz-scaling, expectations (Hoffman \& Yeh 2018), and in part by their own aspirations, anchored in hypothetical and anticipatory claims about distant futures (Garud, Schildt and Lant 2014; Mische 2009; Wood, Bakker and Fisher 2021). Importantly, such expectations and aspirations when articulated in pitches are not symbolic in nature but become performance goals, against which entrepreneurs and their ventures are evaluated (Garud, Gehmanand Tharchen 2017). For example, Elizabeth Holmes founded Theranos to develop a blood analysis device that could conduct over one hundred highly reliable tests on a single drop of blood, a goal that became the endpoint of the yardstick used to evaluate her and her venture's performance (Carreyrou 2018).

Performance strain makes entrepreneurs vulnerable to two types of misconduct. On the one hand, entrepreneurs may engage in performance enhancing misconduct, in which they employ fraudulent means to obtain their performance goals. For example, Theranos entered into a contractual agreement with Walgreens to use its signature technology, the Edison, to conduct a large a long list of tests on (just a few drops of) the drug store's customers' blood. But when the venture struggled to perfect the technology, its founders authorized the use of commercially available blood analyzers (rather than the Edison) to conduct the tests (Carreyrou 2018). Similarly, when Ubiome struggled to develop its technology for analyzing the micro-organisms populating the adult human 
gastrointestinal tract, its executive team endorsed a shortcut that entailed substituting the analysis of adult human feces with the analysis of infant and pet feces. What is more, when Ubiome's sales did not meet financial projections, top managers pressured contracted doctors to order tests that patients did not need (Brodwin et. al., 2019).

On the other hand, entrepreneurs can engage in performance misrepresenting misconduct, in which they employ fraudulent means to represent their goal attainment. For example, when the startup Just Mayo failed to meet sales projections upon which prospective investors were focused, its founder Josh Tetrick instructed employees to buy cases of the startup's vegan mayonnaise off grocery store shelves, inflating the company's sales figures (Zaleski, Waldman, and Huet, 2016; Bercovici 2017).

\section{Perverse Incentives}

Organizational misconduct also often is attributed to perverse incentives. Organizational participants tend to be formally rational; that is, they tend to engage in behaviors that simultaneously maximize benefits and minimize costs. When incentives are well aligned, they give rise to stable work relationships that allow organizations to function efficiently and effectively. But when the projected benefits of wrongdoing outweigh the anticipated costs (which are a function of the likelihood of detection and the magnitude of punishments), organizational participants have an incentive to engage in misconduct (c.f., Becker 1968). More specifically, agency theorists argue that top managers have an incentive to engage in self-serving misconduct (e.g., the misappropriation of funds) if they are not major stockholders of their firm, in which case their interests diverge from the interests of the firm's stockholders, which are linked to their firms' long-term welfare. Agency theorists assert, though, that top managers' incentive to engage in misconduct is held in check when the firm's stock is concentrated in the hands of a few individuals or institutions and/or the firm is overseen by an independent board of directors, both of which are capable of monitoring and disciplining top managers' parochial errant behavior (Fama 1980; Fama and Jensen 1983).

Agency theorists would expect that entrepreneurs have little incentive to engage in misconduct that can undermine their firms' long-term prospects, insofar as they are principal owners of their ventures (Garg 2013). But we think some types of entrepreneurs face unique cost-benefit tradeoffs that can motivate them to engage in misconduct. Specifically, serial entrepreneurs may be prone to misconduct because they prefer starting ventures rather than managing them over the long-term. For example, research has shown that vulnerabilities may arise when entrepreneurs begin to disengage from their venture (Rouse 2016) and when entrepreneurs found a start-up in a new industry after venture failure (Eggers and Song 2015).

Consider the example of Trevor Milton who founded a series of ventures, some of which he exploited for personal gain and each of which he fraudulently portrayed as more valuable than they were before selling or relinquished control of them at a profit. Most famously, after founding several businesses under the radar of media scrutiny (an ADT alarm company franchise, a classified-ad website called uPillar, and a natural gas diesel fuel truck company called dHybrid), he founded the hydrogen fuel cell powered truck startup Nikola. After achieving "unicorn" status, Milton reportedly extracted from the startup and its investors loans and cash sufficient to purchase a \$2.15 million home, a \$32 million ranch, and three private planes (including a Gulfstream G-V jet). Then he exited 
the venture in the short period of time between its successful initial public offering and a short seller's revelation of the startup's fraudulent character, leaving the enterprise with an estimated \$94 million. Milton was recently indicted for securities fraud (Ramey 2021) and Nikola, which is under investigation by the Department of Justice and the SEC, has lost several high-level partnerships, and now trades at a fraction of its former stock market value (Foldy, Colias, and Naughton 2020).

In addition, we think incentives-related vulnerabilities to entrepreneurial misconduct increase when ventures raise large sums of money for which there is no public accountability and hence formal oversight. Over the past decade, the ticket size of startup investments has greatly increased (Joint Venture, 2020), often driven by intensive capital requirements to fund high-growth aspirations and fueled by capital providers' abnormal return expectations. A recent New Yorker article described one instance of venture capitalists' inclination to invest massive sums of money into startups. It chronicled the experience of Jeremy Neuner, who founded NextSpace. Neuner's venture was an early entrant to the co-working real estate industry that employed a business model similar to the model employed by WeWork, but Neuner had more modest financial aspirations (and projections) than his competitors.

"Venture capitalists began telling Jeremy Neuner that making piddly investments in his company wasn't worth their time ... To Neuner, this seemed nuts. He was building a solid business, but the V.C.s wanted fantasy. "All we needed was five million dollars a year in revenues, and we would have made money for everyone," he told me. "That's enough to earn a living and buy a house and put your kids through school. But no one wanted something that just made a healthy living. They all wanted to find the next Zuckerberg." Neuner was frustrated, but he wasn't surprised. He knew that American history was filled with entrepreneurs like P. T. Barnum, Walt Disney, and Charles Ponzi, self-promoters whose audaciousness created new industries and vast riches - and who, occasionally, ended up in jail. What Neuner hadn't realized was that some venture capitalists had become co-conspirators with such hype artists, handing them millions of dollars and encouraging their worst tendencies, in the hope that one lucky wager would more than offset many bad bets" (Duhigg 2020, p.38-39).

We think risk capital investors' appetite for placing big bets play a role in promoting or tolerating entrepreneurial misconduct. Arguably most important, venture capitalists who place big bets on startups typically receive seats on their board of directors and thus are formally tasked with monitoring and disciplining the ventures. Yet, research has shown that risk capital investors can become complicit in their investees' misconduct when they hold a short-term commitment to them. Many venture capitalists hope to exit the startups in which they invest between founding and IPO or acquisition, and thus are motivated to overlook concerns that if made public might undermine their investments' value (Guler 2007). For example, the venture capital firm SoftBank invested $\$ 300$ million into WeWork with minimal oversight. In turn, WeWork's founder Adam Neuman purchased a $\$ 60$ million corporate jet, installed an infrared sauna and a cold plunge pool in his Manhattan office, purchased properties that he subsequently leased back to the firm, trademarked the word "We" and charged the venture \$5.9 million for use of it, and ultimately extracted $\$ 700$ million from the venture (Chozick 2019; Farrell et al., 2019; Duhigg 2020). WeWork's board of directors was staffed by venture capitalists (with the exception of Lewis Frankfort, the former chairman and CEO of the multinational luxury 
fashion firm Tapestry, Inc.) who only censured Neuman when the startup's planned IPO turned sour. As potential buyers and short sellers scrutinized the startup's S-1 prospectus and discovered its performance misrepresentations, WeWork's valuation dropped from $\$ 47$ billion to $\$ 8$ billion and the venture was forced to abandon its IPO ambitions (Farrell et. al., 2019). Subsequently, New York State's Attorney General opened an investigation of Neuman for misappropriation of funds and the SEC opened an investigation of the venture for IPO filing rule violations.

Further, as principal owners, entrepreneurs exercise inordinate control over the selection of the balance of their ventures' directors (i.e., over the selection of non-venture capitalist directors). Entrepreneurs often use this control to select directors who lend general legitimacy to their ventures, but who lack expertise to scrutinize them closely. As a result, entrepreneurs who engage in wrongdoing often are at diminished risk of detection and discipline by their boards of directors, agency theorists' key failsafe. The capacity of boards of directors to discipline wayward entrepreneurs is particularly compromised in the case of high-technology ventures that operate under extreme uncertainty. These ventures are founded to develop and commercialize new technologies as well as create new industries about which there is little prior expertise. As a result, the board of directors may know little about their ventures' emerging technologies and may be illequipped to monitor their internal operations. For example, Elizabeth Holmes recruited the well-known high-ranking former government officials Charles Schultz and Henry Kissinger to serve on Theranos's board of directors. Schultz and Kissinger possessed no medical technology expertise and thus subsequently backed Holmes when confronted with whistleblower allegations of her malfeasance (Carreyrou 2018).

\section{Flawed Administrative Systems}

Organizational wrongdoing also has been attributed to flawed administrative systems (c.f., Krawiec 2005). Administrative systems segregate tasks and the people who perform them into specialized subunits and positions. They also elaborate behavioral prescriptions (rules, standard operating procedures, and the like) that dictate how organizational participants should conduct themselves within differentiated subunits and positions. When administrative systems are well designed, they articulate behavioral prescriptions that clearly demarcate the line separating right from wrong and evolve subunits that specialize in the monitoring and disciplining of errant behavior. When administrative systems are not well designed, though, they can allow misconduct to flourish. For this reason, the reformation of organizations found to have engaged in or been the site of misconduct typically includes reinforcement of their administrative systems (c.f., Valukas 2014; Wainstein, Jay and Kukowski 2014).

We think entrepreneurial ventures tend to employ administrative systems that are vulnerable to misconduct. The older, the bigger, and the more technologically routinized an organization becomes, the more elaborated its administrative systems tend to be (Pugh et. al., 1969). Entrepreneurial ventures are nascent, small, and utilize unproven technologies. Thus, their role structures tend to be flexible, their routines minimal, and their decision-making centralized in the hands of a few, engendering an overall low administrative intensity (Sine, Mitsuhashi and Kirsch 2006; DeSantola and Gulati 2017). Further, startups tend to forgo the creation of administrative units specializing in the monitoring and disciplining of errant employee behavior. 
Elon Musk's transgression of Securities and Exchange Commission guidelines has been attributed to inadequacies in his venture's administrative systems. On August 7, 2018, Musk issued a tweet touting Tesla's readiness to go private at $\$ 420$ a share, offering a substantial premium to the startups trading price on the stock market and leading to a spike in the venture's trading volume and share price. The SEC ruled that Musk's tweet constituted fraud and imposed on him and the firm fines of \$20 million. Further, it attributed Musk's actions to the fact that "Tesla had no disclosure controls or procedures in place to determine whether Musk's tweets contained information required to be disclosed in Tesla's SEC filings. Nor did it have sufficient processes in place to (insure) that Musk's tweets were accurate or complete." Hence, as part of the settlement between Musk, Tesla, and the SEC, the startup was required to institute governance reforms that included the establishment of a new committee of independent directors and the elaboration of "additional controls and procedures to oversee Musk's communications" (Securities and Exchange Commission 2018).

Similarly, Tylor Shultz's difficulty in voicing concerns about fraudulent behavior at Theranos might be attributed to inadequacies in that startup's administrative controls. Shultz, a relatively low-level employee, came to believe that his superiors were misrepresenting the reliability of the startup's core technology, the Edison. He raised his concerns with the manager responsible for generating the device's reliability statistics, who assured him that the statistics were sufficiently accurate. Unconvinced, Shultz sought another internal authority to whom to convey his concerns. But Theranos did not have a compliance department, so he elevated his concerns to the venture's founder Elizabeth Holmes. To Shultz's dismay, Holmes recommended that he again speak with the executive responsible for generating the reliability statistics. Becoming increasingly concerned that Theranos was misrepresenting the reliability of the Edison and feeling that he was getting nowhere in his attempt to have his concerns taken seriously, Shultz chose to leave the firm and make his concerns known to state regulators. But Theranos also did not have a human relations department, so he penned his resignation letter directly to Holmes. As Shultz wrote, "I feel like I owe you this bad attempt at an exit interview since we have no HR to officially record it." (Carreyrou 2018).

\section{Misaligned Cultures}

Organizational wrongdoing also has been attributed to misaligned cultures (c.f., Sims and Brinkmann 2003; Kulik 2005). Organization theorists have conceptualized culture in a multiplicity of ways (Giorgi, Lockwood, and Glynn 2015). We employ an integration of these theorizations that understands culture to be comprised of content and form (Palmer and Feldman 2017). Cultural content consists of shared assumptions about the nature of an organization's internal and external environment (e.g., taken for granted understandings about the degree to which the environment is inherently cooperative as opposed to competitive), shared beliefs about the value of different types of behavior in the environment (e.g., beliefs about the degree to which it is good to be cooperative), and normative prescriptions regarding how organizational participants should behave (e.g., shared convictions about the degree to which organizational participants should cooperate with one another). Cultural forms, which telegraph cultural content to organizational participants, consist of artifacts (e.g., jargon and mantras) and practices (e.g., after work get-togethers) that typically have both practical and symbolic value. When cultural systems feature content that aligns organizational participant behavior with ethical principles, social norms, and legal restrictions, they constitute a firewall against 
misconduct (c.f. Trevino and Nelson 2017). But organizational cultures also can facilitate misconduct in and by organizations in two ways.

First, culture can explicitly endorse misconduct, when it features assumptions, values, and norms that directly promote behaviors constituting wrongdoing (Palmer 2013). Several cultural artifacts found in entrepreneurial ventures and the entrepreneurship field convey content that explicitly endorses misconduct. For example, the "fake it until you make it" mantra espoused by entrepreneurs and other stakeholders in the field can be understood to explicitly endorse the norm of misrepresenting one's ability to deliver on projected performance goals at intermediate points in time to gain access to critical resources needed for ultimate success. Robert Boback may have embraced this mantra when he installed phony computer towers with blinking lights to give potential investors the impression that Triversa's security software exploited more powerful hardware than it actually required (Khatchadourian 2019). Similarly, Josh Tetrick may have embraced this mantra when he mis-represented Just Mayo's financial potential by generating wildly over-optimistic sales projections, a gambit that allowed him to attract additional investors but also led to U.S. Securities and Exchange Commission and Justice Department probes (Zaleski et. al. 2016; Bercovici 2017).

Further, some techniques routinely employed by entrepreneurs represent cultural practices that can endorse misconduct. For example, the creation of product facades to convey to consumers and investors the intended characteristics of products and services, referred to as "pretotyping" and "minimum viable products," also can be understood to endorse the norm of misrepresenting a firm's actual capabilities (Savoia 2019, Ries 2011, Blank 2013). Trever Milton's misadventures at Nikola illustrate the potential link between these cultural practices and misconduct. Milton displayed his venture's signature hydrogen fuel cell powered semi-truck, the Nikola One, at a product launch event in 2016, characterizing it as "not a pusher" (i.e., not a mock-up vehicle). A year later he released a video of the Nikola One that appeared to show the truck travelling down a highway under its own power. But the truck, in fact, was not operational at either time. In 2020, after the subterfuge was unmasked by the short seller Hindenburg Research, Nikola and Milton issued a carefully worded statement that characterized the 2016 portrayal and the subsequent video as essentially truthful. Among other things, they claimed that the firm's investors knew the truck's actual state of development in 2017 and noted that the misleading video was described on social media only as showing the truck "in motion" (Korosec 2020). But the startup's stock price cratered and its key partnership with General Motors was scaled back. Soon thereafter, as noted above, the Department of Justice and the SEC opened investigations into the venture and indicted Milton for fraud (Boudette and Ewing 2020; Eisenstein 2020).

Second, cultural content can implicitly endorse misconduct, when its assumptions, values, and norms endorse behaviors that do not constitute wrongdoing, but can lead to misconduct (Palmer 2013). We think the scholarly and practitioner discourse that characterizes entrepreneurship as "creative destruction," entrepreneurial action as inherently "disruptive," and employs mantras like "move fast and break things," and "fail fast, fail early, fail often" can have this effect. Taken together, these cultural forms imply that entrepreneurs must violate industry norms if they wish to be successful and by extension that it is good for entrepreneurs to violate norms and thus that they should do so. To the extent that entrepreneurs embrace this cultural content, they place themselves on a moral slippery slope to misconduct. In addition, these cultural forms imply that 
entrepreneurs must implement decisions quickly, that it is good for entrepreneurs to fail, and thus that they should embrace rather than eschew failure. This cultural content implies that the costs of acting without deliberate forethought as well as the costs of resulting failure to the startups' employees, investors, or customers either are minimal or outweighed by anticipated ultimate benefits. To the extent that entrepreneurs embrace this content, they can become susceptible to employing the "denial of harm" and "balancing the ledger" techniques of neutralization that enable people to engage in misconduct by blunting the guilt they otherwise would feel from engaging in wrongdoing (Sykes and Matza 1957; Ashforth and Anand 2003; Palmer 2008).

We think the Massachusetts Institute of Technology (MIT) Media Lab, formed to incubate research projects with commercial potential, featured cultural artifacts that supported the cultural imperative to disrupt business norms that might have facilitated misconduct at the lab. Each year the Lab awarded a \$250,000 prize to the researcher who stood out for "engag(ing) in responsible ethical disobedience" (Gluckman 2019). This exhortation to engage in disobedience might have led the founder of the Media Lab's Open Agriculture Initiative, Caleb Hunter, to violate Massachusetts's wastewater dumping regulations and subsequently stonewall regulators' request for readily available data on the dumping, neither of which could be considered responsible or ethical (Song and Larkin, 2019). The MIT Media Lab also featured cultural artifacts that might have telegraphed the imperative to act quickly. The Media Lab's director, Joichi Ito, often reminded lab project leads of their pressing need to "deploy or die," where deployment meant transforming one's research project into a commercial endeavor. This mantra conveyed the norm that project leads should bring their innovations to market quickly, rather than dwell in the research phase, which was equated with death. The norm to move quickly may have caused Caleb Hunter to mis-represent his project's progress towards developing a commercially viable "food computer" that could replicate in small containers growing environments found anywhere in the world (Gluckman 2019).

Embracing cultural content that endorses disruptive business models may be particularly problematic in fields such as healthcare, where established normative systems protect stakeholders' interests and "people's lives (may be) in the balance" (The Inventor, 2019). For example, the online psychotherapy startup Talkspace developed a business model that violated several industry norms that protect therapy clients' interests. The startup features its services in highly public and very explicit advertisements that experts contend can provoke symptoms and distress in psychologically vulnerable persons. Further, Talkspace uses data mining techniques to analyze its growing volume of recorded patient-therapist sessions for the purpose of "improving" its therapists' services but does so in ways that have violated client confidentiality. Finally, its signature feature of offering clients on-demand access to therapists violates a central principle of most psychotherapeutic approaches, which is to maintain clear temporal boundaries between the beginning and end of therapy sessions (Hill and Krolik 2020).

Finally, startup culture also may give rise to a particular type of misconduct, the sexual harassment and assault of women. Entrepreneurial ventures tend to be founded and populated in the early stages by men. Consequently, they tend to feature "bro cultures," in which assumptions, values, and norms support androcentric interactions and the treatment of women as both outsiders and objects of male sexual interest (for comprehensive overview see Fowler 2020). Patriarchal cultures are thought to be conducive to the sexual harassment and assault of women (hooks 2004). A survey of 950 
startup founders and employees found that one in two workers either had been sexually harassed or knew someone who had been harassed in the workplace (First Round, 2019). Planswell, a Canadian financial planning startup, appears to have featured a "bro culture" that may have been conducive to sexual harassment. Reportedly, male executives frequently peppered their conversations with sexual innuendo. On one occasion, the male dominated leadership team discussed employing prostitutes to celebrate the end of an offsite meeting. On another, a male executive brought a female gendered sex doll to work, dressed in a Planswell T-shirt. Events came to a head when a young female employee requested that Planswell's male marketing director, who had pursued her romantically, restrict their interactions to work-related matters. Within days she was fired. After experiencing little success in pressing her case with the company's CEO, the female employee went public with her allegations of harassment, contributing to the firm's demise (Hensley 2020). ${ }^{4}$

\section{Skewed Power Structures}

Organizational wrongdoing also has been attributed to skewed power structures. Power, which is the capacity to get what one wants over the resistance of others, takes two forms in organizations, the first of which is formal power or authority. Formal power is rooted in the chain of command and based on the norm of obedience. The higher a person is in the chain of command, the more authority they possess over others in the organization. When well designed, formal power relations provide a means for addressing problems that are not anticipated by an organization's administrative systems. But as Milgram (1963) famously showed, authority also can be used to compel people to participate in misconduct.

We think formal power relations in entrepreneurial ventures are uniquely prone to facilitate misconduct. Authority relations always rest on legitimating criteria, of which there are three main types: charismatic, religious/traditional, and rational/legal (Weber 1922/1978). When formal power is legitimated by charismatic criteria, authorities retain their positions based on their presumed possession of extraordinary qualities (e.g., as was the case with Prophet Muhammad). When formal power rests on religious criteria, authorities retain their positions based on presumed sacred authorization (e.g., as is the case with Pope Francis). When formal power rests on rational-legal criteria, authorities retain their positions based on merit or ownership of the enterprise (e.g., as was the case with Rex Tillerson at Exxon and Henry Ford II at Ford Motor Company, respectively). Formal power legitimated on rational/legal criteria only allows authorities to issue orders narrow in scope (orders that pertain to subordinates' organizational roles), whereas formal power legitimated on charismatic or religious criteria allows authorities to issue orders broader in scope (orders that pertain to subordinates' organizational and nonorganizational roles). In most contemporary organizations, leaders' formal power is legitimated on rational and/or legal grounds. But in entrepreneurial ventures, leaders' authority often rests partly on charismatic and sometimes even quasi-religious grounds (Lovelace, Bundy, Hambrick \& Pollock, 2018). Start-up founders frequently are

\footnotetext{
${ }^{4}$ This example also illustrates the frequent interconnectedness of the various causes of misconduct. The female Planswell employee brought her complaint to the firm's CEO, because the firm's HR department was only recently established and thus had little independence and clout. Further, the HR director was given the rather informal title of "Director of People," a cultural artifact that telegraphed the lax approach it would take when addressing workplace misconduct.
} 
portrayed (and sometimes portray themselves) as heroic figures, possessing one-of-a-kind exceptional qualities, including unique foresight regarding the needs and possibilities of the human enterprise (Stephen, 2018; Zuckerman, 2017). And as such, they possess broad authority to enlist the support of subordinates in their preferred courses of action, including the perpetration of misconduct (Chatterjee \& Pollock, 2017).

Theranos founder Elizabeth Homes appears to have derived at least some of her authority from perceived charisma. Theranos board members General James Mattis and Henry Kissinger described her as "a true revolutionary" and "ethereal," respectively. Board member and renowned Stanford University engineering professor Channing Robertson judged Holmes to be a once or twice in a century personage on the par of Archimedes. Holmes was said to require only four hours of sleep and observed to seldom blink in interpersonal interaction, so abundant and focused were her energies. Holmes's status as a charismatic authority appeared to play a role in deterring subordinates from resisting her questionable directives, as Tyler Shultz vividly described during an event at Stanford University:

"She was extremely charismatic. I would go into her office, and she would tell me about the vision of the company and helping third world countries. I would be so motivated to do my job. I would go back, and I was working with the Theranos device, and I go: 'What has just happened? How did she just do that to me?' I was working with this device everyday but in a five-minute conversation with her she was able to change my mind and for me to feel motivated again. I can see how, if you weren't actually working with the device every day, how easy it would be for her to convince you that this was real and that all these things were happening." (Spilling the Blood of a Silicon Valley Unicorn, 2019)

Similarly, Hampton Creek founder Josh Tetrick appears to have derived some of his authority from perceived charisma. One Hampton Creek employee characterized Tetrick as resembling a "religious pastor" whose vision of fixing a corrupt corporate food system made her feel "blessed to have met him." Subsequently reflecting on some of the questionable things she did at his direction, the employee wondered, "Why did I do things that made me really uncomfortable, that I knew weren't right?" (Zaleski et. al. 2016).

Power also takes the form of informal power or resource dependence in organizations. Informal power is rooted in the distribution of scarce and important resources and based on the dependence relationships this distribution engenders. The more one controls resources that are scarce and important to others, the more informal power one possesses over others. Informal power allows organizational participants to obtain the compliance of others who are above or on the same level as them in the chain of command; that is, superiors and peers. Such power relationships can facilitate organizational adaptation to changing environmental conditions (Salancik and Pfeffer 1977). But when not managed effectively, they also can facilitate misconduct (Palmer 2013). We think that informal power relations in entrepreneurial ventures also are uniquely prone to facilitate misconduct.

Founders of entrepreneurial ventures often control scarce resources that are crucial for their startups' success, such as unique technological expertise, market insight, and social capital. Founders' control over these scarce resources can allow them to compel their 
ventures' stakeholders to facilitate or refrain from impeding their misconduct. In extreme cases, the control of unique technological expertise, market insight, and social capital has allowed founders to create dual-class shares, retaining 20-to-1 super-voting rights stock ownership of their ventures (Davis 2016, Berovici 2019). Founders who own supervoting rights stock are particularly well-positioned to control appointments to their ventures' boards of directors, thereby blunting their boards' capacity to fulfill their legally mandated oversight responsibilities, even when founders only own a minority of their startups' shares. In the event of absent board oversight, founders are free to pursue their parochial interests at the expense of ventures' other stakeholders.

For example, Adam Neuman's perceived control of unique real estate market insight allowed him to retain super-voting rights ownership of WeWork, which allowed him to control appointments to the startup's board, which in turn compromised the board's ability to fulfill its oversight responsibilities. As noted above, in the years that followed, Neuman directed WeWork to purchase the "We" trademark from him for \$6 million, to lease his privately owned properties for additional untold millions, and to pay him $\$ 700$ million in advance of the venture's planned public offering. Finally, after the public offering was aborted due to growing awareness of WeWork's weak financial position, Neuman engineered a golden parachute exit that netted him a $\$ 1.7$ billion severance package (McGreggor 2019; Molla 2019). Neuman's self-dealing ultimately led to investigations by the SEC and the New York Attorney General (Lutz 2019; Reuters 2019). Super-voting rights control of Uber by Travis Kalanick and of Lyft by Logan Green and John Zimmer may have facilitated misconduct at these ventures, which we discuss separately below (Berovici 2019).

The theory and examples above testify to the way in which power relations can facilitate misconduct in new entrepreneurial ventures. But recent research suggests that extreme power differentials also can motivate wrongdoing in organizations; elaborating the wellknown Lord Acton adage, "power tends to corrupt and absolute power corrupts absolutely" (Acton 1887). This research indicates that powerful persons tend to treat those over whom they have power with disregard, violating their interests, rights, and justice claims (Keltner et. al., 2003). The impact that power has on the motivations of the powerful may be particularly significant in new entrepreneurial ventures, where founders not only enjoy expansive formal authority partly based on their perceived charisma, but also possess substantial informal power based on their perceived control of unique technological expertise, market insight, and social capital. The alignment of formal and informal power may have created a perfect power storm at WeWork, where Adam Neumann portrayed himself as a charismatic figure (he was reported to voice his intention to become the world's first president and hoped to expand his company to the planet Mars) and possessed resources on which the firm's financial success was believed to rest (a belief incorporated in the venture's S-1 public offering prospectus). Neuman often treated his subordinates in arbitrary and humiliating ways, in one instance requiring a group of managers to drink days old dregs of discarded beer bottles and in another publicly referring to his chief of staff's pregnancy and subsequent maternity leave alternately as a "vacation" and "retirement" (Chozick 2019; Baca 2019).

\section{Social Influence and Group Dynamics}

Organizational participants can influence one another's actions, thoughts, and even feelings, sometimes as due to their coalescence into small informal groups. Social 
influence and group dynamics long ago were recognized as benefiting organizations by providing their members with intrinsic motivation to stay on the job and hard to codify guidance on how to perform their assigned tasks (Roethlisberger and Dickson, 1947; Roy 1959; Barnard 1968). But social influence and group dynamics also can facilitate organizational misconduct (Brief et al. 2001; Ashforth and Anand 2003; Palmer 2008). We think new entrepreneurial ventures are uniquely susceptible to the dark side of these individual and group-level influence processes.

Venture capitalists are susceptible to social influence processes that can undermine their capacity to provide oversight of wayward entrepreneurs. Angel investors and venture capitalists typically make their investment decisions under high uncertainty, with limited objective quantifiable information, relying on their intuition and "gut" feel (Huang 2019). Early-stage investors tend to rely heavily on their assessments of entrepreneurs' personal characteristics, derived from close personal interaction and observation (Huang \& Pearce 2015). Tim Draper, among the first investors to jump on the Theranos bandwagon, vividly explained venture capitalists' tendency to focus on the founder when making investment decisions.

"I invest when I see a vision, I see the opportunity, and I see the person who I think can make it there. I mean we invest in, you know, a girl and a dog or two guys and a cat. We just say is this person going to dedicate their life and make something extraordinary happen. And yes, in that case (Theranos), she (Elizabeth Holmes) was that person." (The Inventor 2019, emphasis and parenthetical expressions added).

Venture capitalists" intuition or "gut" feel is guided by their attraction to entrepreneurs, and their attraction to entrepreneurs frequently is based on similarity. Ethnic and cultural matching along dimensions that are irrelevant to the venture in question, such as gender, ethnicity, educational background, and hobbies, often are the basis of investment decisions (Bengtsson \& Hsu 2015; Rivera 2012). Social psychologists have shown that interaction between similar others leads to liking and, over extended periods of time, friendships (Cialdini 2001). Liking and friendships can blind investors to early signs of misconduct. ${ }^{5}$ For example, prominent Theranos investors and board members developed personal relationships with Elizabeth Holmes, ties that might have impaired their ability to see red flags in her behavior. Former US Secretary of State and Stanford University Hoover Institution scholar George Shultz welcomed Holmes into his home, inviting her to holiday and birthday celebrations. Shultz's close personal relationship with Holmes apparently blinded him to signs that she and Theranos were engaged in fraudulent behavior, signs that he ignored even though they were conveyed to him by his grandson Tyler who worked for the startup (Carreyrou 2018; The Inventor 2019). Similarly, SoftBank's CEO Masayoushi Son developed a close personal relationship with Adam Neumann, which many believe blinded him to Neumann's self-dealing (Chozick 2019; Ferrell et. al., 2019). ${ }^{6}$

\footnotetext{
${ }^{5}$ The overreliance on intimate relationships and gut feel seals off the entrepreneurial domain from underrepresented groups, as is evident in recent figures of total capital invested in entrepreneurial ventures, which indicate that only $2.7 \%$ of startups are female led (Pitchbook 2021) and only $2.6 \%$ are African American and Latinx led (Crunchbase 2020).

${ }^{6}$ These social influence traps may be circumvented when financial backers are large public corporations, such as those seeking to acquire innovations related to their existing lines of business. Many such corporations have evolved specialized units to police questionable behavior and eschew connections to
} 
What is more, we suggest startup top management teams are vulnerable to group dynamics pressures that can compromise their members' moral compasses and insulate them from outside criticism. As noted above, entrepreneurs often launch and staff their start-ups with family members and friends (Ruef, Aldrich, \& Carter, 2003). Further, founding teams typically work in close physical proximity for long hours and cultivate an informal atmosphere in which the line between work and play is blurred (Wasserman 2012). Finally, founding teams often understand themselves to be pursuing noble objectives, against inefficient systems and specific antagonists. Such group dynamics can give rise to strong informal group forces (Shaw 1936; Feldman 1984) and can lead founding team members to tolerate and even facilitate their colleague's misconduct. In extreme cases, these dynamics can render founding group members susceptible to groupthink, a state in which informal group members consider themselves morally and otherwise superior to outsiders who might question their behavior (Janis 1971, 1972; Ruef, Aldrich, \& Carter, 2003).

Adam Neumann's pursuit of parochial self-interest at WeWork might be attributed partly to intense group dynamics. Neuman hired twenty friends and family members to occupy key positions at his venture, including his wife Rebecca who served as the firm's "chief brand and impact officer" (Brown et. al., 2019). Lower-level WeWork employees referred to the circle of friends and family who were closest to Neumann as the "oval office," indicative of the degree to which the founding team was cut off from the rest of the firm (Baca 2019). Similarly, Robert Boback's embrace of fraudulent marketing practices at Triversa might be attributed partly to groupthink. In conversations with the venture's top managers, Boback expressed disdain for all outsiders, even for the startup's potential clients. When WikiLeaks dumped data that compromised several firms' security, he exhorted members of his sales team to immediately reach out to the exposed firms to offer Triversa's services "before some IT goon in [their] organization tries to convince them that they have it covered" [emphasis added] (Khatchadourian 2019).

Group dynamics also might have added impetus to the misconduct at Theranos. Elizabeth Holmes founded the blood diagnostic venture with her romantic partner and early investor Ramesh (Sunny) Balwani and subsequently brought her brother and several of his college friends on board. Balwani, Holmes's brother, and her brother's friends not only supported Holmes questionable business practices but rooted out and eliminated opposition to them. Holmes and Balwani often encouraged Theranos employees to redouble their efforts by proclaiming that they had embarked on mission to free patient medical data from the control of large healthcare corporations and by contending that powerful firms such as Quest Diagnostics were aligned against them (The Inventor 2019). When employees raised concerns about Theranos's questionable practices, the employees' concerns were brushed aside as indicative of the employees' faint or waning commitment to the venture's lofty mission. If critical employees persisted in their vocal

questionable ventures that if detected might tarnish their public image. Thus, Microsoft recently investigated the conduct of AnyVision, an Israeli facial recognition software corporation in which it held a substantial interest, to determine whether the firm's software, in use at Israel-West Bank border crossings, was being employed by the Israeli government to surveil Palestinians inside the occupied territories. But large corporate financial backers' power to alter a startup's questionable behavior may be limited if they do not hold a majority stake in the venture. Hence, when Microsoft determined that AnyVision's involvement in the Israeli government's surveillance activities might be problematic, its only recourse was to sell its minority stake in the firm (Dastin 2020). 
disapproval of a company practice, they were "encouraged" to quit and, if they obliged, were summarily marched off the venture's premises (Carreyrou 2018; Ramsey 2019; The Inventor 2019).

\section{Escalating Commitment}

Organizational wrongdoers are often portrayed as having slid down a "slippery slope" that began with questionable behavior and ended with indisputable misconduct. The progression down such a slippery slope can entail escalating commitment, a process in which people become wedded to a course of action by taking incompletely rational incremental steps consistent with the course of action, while developing post hoc rationalizations for each successive incremental step. People are most likely to escalate their commitment to a course of action when they believe they are responsible for their incremental acts, others are aware of their acts, and their actions are difficult or costly to reverse (Cialdini 2001). Commitment processes can indirectly facilitate misconduct, by leading organizational participants to become psychologically invested in pursuing a futile objective, a process known as "escalating commitment to a failing course of action" (Staw 1976). Commitment to a futile pursuit can lead to strain, which as we note above is one recognized cause of organizational misconduct. Commitment also can directly facilitate misconduct, by leading organizational participants to become incrementally psychologically invested in a wrongful course of action (Palmer 2013). We think entrepreneurs are uniquely susceptible to both commitment-related causes of misconduct.

Entrepreneurs often become committed to pursuing unobtainable goals in an incremental fashion, of their own volition, in view of others, and with few options to reverse course. Entrepreneurs seeking risk capital investment must convincingly portray their nascent enterprises as possessing limitless technological and financial potential to satisfy venture capitalists' high-risk, high-return appetites. They accomplish these portrayals by constructing ambitious public narratives that project exponential growth, formalized in concrete performance goals (e.g., the accelerator Y-Combinator known for its prescription of 5-7\% weekly growth). Entrepreneurs who successfully secure venture capital backing are expected to meet their self-determined out-sized performance goals (Garud, Gehmanand, and Tharchen 2017; Garud, Schildt and Lant 2014). Often, funded startups are forced to raise additional rounds of financing to sustain their scaling trajectory, because entrepreneurial ventures often do not generate revenue and are lossmaking entities with high cash "burn rates." If entrepreneurs fail to meet their performance goals and have no more runway (i.e., their venture runs out of cash), they are faced with a potential penalty, a "down round" which decreases the company's valuation and implies managerial failure as additional company shares must be sold at a lower price than in the previous financing round. While the practitioner literature describes a backdoor that allows entrepreneurs to quasi-reverse their course of action and "pivot" to a new business model, we think failure to achieve performance goals in the presence of market penalties and investor pressures can increase entrepreneurs' determination to succeed (Grimes 2018). Thus, the brink of failure can motivate entrepreneurs to pursue additional financing to make up for lost ground, in the process generating even more ambitious performance goals, further intensifying the misconduct inducing strain to which they tend to be subject.

Further, entrepreneurs' transition from honest to dishonest pursuit and representation of goal attainment can itself entail an escalating commitment. When this is the case, the 
transition begins with questionable behavior and ends in clearly illegal acts, a process intensified by feelings of personal responsibility, public visibility, and perceived irreversibility and facilitated by the embrace of rationalizations consisting of one or more techniques of neutralization. For example, Caleb Harper engaged in increasingly deceptive practices to overstate his MIT Media Lab project's success. Initially Harper simply overstated his Open Agriculture Initiative's technological capabilities. Overtime he embraced increasingly daring ruses, such as misrepresenting store-bought greens, herbs, and flowers as products of his project's "food computers." In response to criticisms of his tendency to misrepresent his venture's technological capabilities, Harper offered a justification that combined elements of the denial of responsibility and balancing the ledger techniques of neutralization.

"It's vision versus reality, and both are necessary... I have a pretty good handle on where the field is going. So, I talk about that. And because I'm so clear on that vision, I think people misinterpret that as reality" (Gluckman, 2019: A15).

It is clear from this quote that Harper recognizes that his rhetorical tactics cause audiences to confuse his vision with reality. But, in his eyes, his audience is to blame for failing to discern the difference between his entrepreneurial vision and his startup's reality, a manifestation of the denial of responsibility justification. Further, it is clear from this quote that Harper believes entrepreneurs must embrace both vision and reality if they hope to be successful, even if his doing so misleads his audience. Thus, in Harper's eyes, characterizations of his venture's capabilities that mislead his audience are a necessary concomitant of its ultimate success, a manifestation of the balancing the ledger justification.

Similarly, Theranos began its descent into wrongdoing by overstating the number of tests its blood analysis prototype, the Edison, could perform. Subsequently, the venture misled investors and strategic partners about the reliability of the presumably market-ready blood analyzer, over 10 successive investment rounds in which USD 1.4 billion were raised. Ultimately, it orchestrated an elaborate scheme to mislead investors, strategic partners, employees, and patients about the method it used to test patient blood. Theranos pulled off this scam by engineering office walls so that only a few employees with special clearance could access the Edison, obligating every visitor to sign a nondisclosure agreement, and even prohibiting Theranos employees to publicly display their affiliation with the firm in public. These measures erected a veil of secrecy around the venture, helping its founders Holmes and Balwani to secure further investments as the gap between projected performance goals and actual startup performance widened (Carreyrou 2018, The Inventor 2019).

\section{Institutional Factors}

Recently, institutional theory has been tapped to explain organizational misconduct (c.f., Gabbionetta, et al. 2013). Institutional theory offers an overarching framework within which to analyze organizational environments. Scott (2013), the first to articulate the institutional perspective in a unified way, identified three structures of which organizational environments are composed: regulative, normative, and cognitive structures. We have already elaborated arguments that implicitly analyze the regulative structures in which entrepreneurial ventures are embedded, noting that the law and enforcement regimes in which startups operate are typically undeveloped and that for this 
reason much startup behavior that incurs public ire is not policed by any formally constituted social control agents. We also have elaborated arguments that implicitly analyze the cognitive structures in which new entrepreneurial ventures are embedded, noting that startup cultures often facilitate misconduct.

We have not, though, yet considered the normative structures in which startups are embedded. Some occupations, such as the medical, engineering, and legal fields, are highly professionalized. These fields can only be entered if one successfully completes a rigorous course of study. Further, after entry into these fields, practitioners often are required to pass periodic examinations to renew their operating licenses and typically are subjected to the discipline of collegial bodies composed of their peers. Some fields within business, such as accounting and engineering, are highly professionalized. But general management is less so and entrepreneurship is not at all. Indeed, the myth of the "dropout" entrepreneur promotes the idea that aspiring entrepreneurs should forgo extensive post-secondary school education of any kind (Watt 2016). This mythology was inspired by some of the most famous and successful entrepreneurs, such as Steve Jobs and Mark Zuckerberg who failed to graduated college. Further, it is sustained by several of the entrepreneurs described here, such as Nikola's founder Trevor Milton who failed to graduated high school and Elizabeth Holmes and Elon Musk who both dropped out of Stanford University. It is even fostered by venture capitalists' intentional interventions, such as Peter Thiel's creation of the Thiel Fellowship, which funds individuals before the age of 23 who opt out of formal education in exchange for an entrepreneurial career. Further, there is no collegial body of peers that monitors and disciplines entrepreneurs. Thus, the founders of new entrepreneurial ventures largely operate on their own, unconstrained by normative systems that otherwise might keep them on the straight and narrow.

\section{Addendum: The Special Case of Platform Organizations}

While high-tech risk capital-financed startups are a subset of all entrepreneurial ventures, they are not a homogeneous subset. Specific types of high-tech risk-financed startups themselves may be uniquely vulnerable to misconduct. Before concluding our analysis, we consider one type of high-tech equity-backed entrepreneurial venture that has captured much media attention; startups that deliver their products or services via independent contractors rather than employees. Such "gig economy" or "platform" organizations use new developments in data science, not to generate new products or services, but rather to monitor, control, and compensate legally independent (i.e., selfemployed) persons who make their products or deliver their services (hereafter, "workers") in new ways, intending to reduce both management and labor costs (Vallas \& Schor, 2020; Rahman 2018). We suggest that these entrepreneurial ventures also are uniquely susceptible to misconduct, albeit in ways not considered above, two of which we briefly elaborate here.

First, platform organizations use technology to control workers at a social and physical distance. While managers of these organizations are full time employees and considered organizational members, their workers are seldom full time and in no case formally considered employees. Instead, platform organizations tend to see workers as nonmembers, users, or customers. Further, workers are globally distributed and seldom interact directly, face-to-face with members of platform organizations. Instead, they communicate electronically, often mediated by sophisticated and automated chat bots. 
Workers who are controlled through technology are less subject to the administrative systems that platform organizations have put in place to curb misconduct. What is more, part-time workers have less incentive to conform to whatever administrative constraints are in place (Siddiqui 2019).

In addition, the social and physical distance that separate managers of platform organizations from their workers likely insulates managers from the guilt they otherwise might feel and that otherwise might deter them from treating their workers unethically (Bazerman and Tenbrunsel 2012). Specifically, the social and physical distance between managers and workers in gig economy ventures might allow the managers of platform organizations to make use of measures that increase worker productivity and optimize platform economics at the expense of worker welfare; for example, by increasing transaction fees and thus decreasing worker payrates without prior notice, as has been the case at Instacart (Bhattarai 2019). Further, as front-line workers feel increasingly squeezed, they may respond by cutting corners. Thus, drivers of so-called ridesharing ventures may be more susceptible to accidents than taxi company drivers (Siddiqui 2019; Rosenfeld 2020).

Second, many platform organizations derive their competitive advantage from circumventing existing legal responsibilities for protecting workers from exploitation and for protecting customers from worker misconduct. For example, in most states gig economy ventures are not required to guarantee their independent contractors the local minimum wage (Conger and Scheiber 2019), nor are they required to put in place structures and processes that protect them from unfair treatment such as gender, race, or sexual orientation discrimination. Further, platform organizations such as Uber and Lyft often escape financial responsibility for compensating accident victims for injuries, reducing their incentive to ensure that their workers drive safely (Rosenfeld 2020).

In sum, new organizational forms open new opportunities for organizational misconduct. In the case of platform organizations, as the distinction between organizational member and non-member remains formally intact, in practice this distinction becomes blurred and ambiguous, giving rise to misconduct by both members and non-members that is uncontrollable by the technological advances that make these organizations possible.

\section{Discussion}

\section{Contributions}

We pursued three interconnected objectives in this chapter. First, we aspired to contribute to theory on entrepreneurship and organizational misconduct. Entrepreneurship theorists tend to portray startups in a uniformly positive light, as engines of innovation that transform markets in ways that improve society. We explore startups' dark side, arguing that they are uniquely vulnerable to known causes of organizational misconduct. Misconduct theorists primarily focus on established, large and bureaucratic organizations. We show that misconduct theory also can enhance understandings of wrongdoing in nascent, modestly sized, informally organized ventures.

Second, we aimed to provide entrepreneurship educators with ideas and case materials to supplement their current approach to examining entrepreneurs' ethical and social responsibilities. Educational programs on entrepreneurship have proliferated broadly, 
making their way into college, secondary, and even grammar school education. We think including theory and evidence on organizational level processes that can give rise to misconduct in startups in entrepreneurship curricula can complement the current pedagogical approach, which focuses on individual level processes that shape ethical decision making (see Byers 2020). Individual level decision making may not suffice to deal with some of the systemic issues that we have highlighted in this chapter. Leaving considerations of organizational level processes off the table may increase the likelihood of entrepreneurship debacles of the sort discussed here. Hence, we recommend educators integrate organizational level tools into entrepreneurship education, such as those designed by the nonprofit organization Project Include (which focuses on increasing diversity and eliminating toxic bro cultures in entrepreneurial ventures).

Third, we averred to send up flares for entrepreneurs and other new venture stakeholders that might alert them to the potential risks in the waters they navigate. If entrepreneurs and other startup stakeholders know where the risks of engaging in misconduct lie, they can take precautionary measures to avoid them. For example, we have shown how risk capital investors' role in startup oversight can be undermined by skewed power structures, renegade group dynamics and misaligned incentives. This suggests that the investor-entrepreneur relationship requires rehabilitation; most importantly, to restore the integrity of the board of directors as a key protector of all stakeholders' interest and a safeguard against misconduct. Hence, we applaud efforts by incubators, accelerators and investors that have gone beyond evaluating a startup's technological and market potential to monitoring and assessing the feasibility of a startup's actual evolving technology.

\section{Limitations}

Our analysis suffers from at least three limitations that future theorists and researchers should address. First, our analysis of high-tech risk-financed startups may not be generalizable to other types of entrepreneurial ventures. We focused on high-tech riskfinanced ventures because they have captured the fascination of scholars, educators, commentators, and the public at large. But high-tech risk-financed startups comprise just a small fraction of the broad spectrum of entrepreneurial activity, much of which neither exploits new scientific discoveries or markets, nor aspires to culminate in public corporations. Most entrepreneurial activity simply seeks to fill unsaturated extant market niches and provide subsistence income (Aldrich \& Ruef, 2017; Welter, Baker, Audretsch, \& Gartner, 2017). Organization theorists interested in misconduct in entrepreneurial ventures would do well to determine whether the arguments advanced here apply to these types of entrepreneurial endeavors as well.

Second and more fundamentally, we do not offer a general theory of entrepreneurial misconduct. Instead, we identify known causes of misconduct in and by organizations to which we argue startups are uniquely vulnerable. We hope that our elaboration of causes of misconduct to which startups might be uniquely vulnerable can provide a foundation upon which a general theory of startup misconduct can be built. We expect that any such general theory at the very least will need to consider how the process of organizational maturation effects entrepreneurial ventures' vulnerability to misconduct. Certainly, startups that have matured to enjoy establishment status, such as Amazon, Facebook, and Google, have not escaped scandal. But a general theory of startup misconduct will need to consider the extent to which the maturation of ventures from startup to established firm, affects the likelihood or the kind of misconduct to which entrepreneurial ventures 
are vulnerable. It will also need to consider whether early misconduct tends to become normalized and imprinted in the organizational design or whether instead it is edited out as startups mature.

Finally, we do not provide empirical validation of our arguments regarding the unique vulnerabilities of startups to the various causes of misconduct we identify. Instead, we describe recent instances of startup misconduct derived from journalistic accounts that we think illustrate our arguments. ${ }^{7}$ We think empirical validation of our arguments (and any future general theory of misconduct in and by entrepreneurial ventures) is necessary to elevate theoretical speculation to the level of social science understanding. We hope that this chapter inspires such empirical analyses. Conducting empirical research on this topic, though, will require overcoming sticky methodological problems, some of which are inherent to the study of organizational misconduct but uniquely problematic in the study of startup misconduct. Most problematic, because entrepreneurial ventures fail at a higher rate than other types of business organizations and because startup failure may be related to misconduct, researchers will struggle to assemble an unbiased sample of startups to study (i.e., a sample in which wayward startups are not under-represented). Also concerning, because startups often operate in regulative grey areas that social control agents are still learning to police, it will be difficult to develop an unbiased measure of misconduct (i.e., a measure that does not capture some kinds of wayward startups more than others).

\section{Conclusion}

In sum, while we believe we have opened an important line of inquiry, we acknowledge that we have only scratched the surface. We think entrepreneurship scholars have overlooked the dark side of startups and organizational misconduct theorists have ignored entrepreneurial ventures. Perhaps for these reasons, entrepreneurship educators concerned about the ethical and social responsibilities of entrepreneurs have focused their pedagogical approaches on individual level determinants of founder behavior. And entrepreneurs have gone blithely into careers, unaware of the potential hazards that await them. We hope this chapter has gone some way towards addressing these deficiencies in theory, pedagogy, and practice in the entrepreneurship domain and that other organizational theorists will find our preliminary effort a useful springboard for more definitive scholarship on misconduct in and by entrepreneurial ventures.

\footnotetext{
${ }^{7}$ We cannot attest to the veracity of our descriptions of startup misconduct because they are derived from journalist accounts, rather than direct observation. Indeed, one entrepreneur featured in our descriptions of startup misconduct (Tiversa's Robert Boback) has disputed the accuracy of the source on which we based our account.
} 


\section{References}

Acs, Zoltan, Astebro, Thomas, Audretsch, Davis, and Robinson, David. 2016. Public policy to promote entrepreneurship: A call to arms. Small Business Economics, Vol. 47, No. 1: 35-51.

Acton, John K. E.1887. Acton-Creighton Correspondence. Available at: https://oll.libertyfund.org/titles/2254.

Aldrich, H. 2019. "What Sustains A Belief in Success Among the Unsuccessful ?" Academy of Management Discoveries.

Aldrich, H., and M. Ruef 2017. "Unicorns, Gazelles, and Other Distractions on the Way to Understanding Real Entrepreneurship in America." Academy of Management Perspectives.

Amore, M., Garofalo, O., and Martin-Sanchez, V. 2020. Failing to Learn from Failure: How Optimism Impedes Entrepreneurial Innovation. Organization Science. Forthcoming.

Ashforth, B. E. and Anand, V. (2003), "The normalization of corruption in organizations", Research in Organizational Behavior, Vol. 25, pp. 1-52.

Baca, Marie. C. 2019. Embattled WeWork co-founder and CEO Adam Neumann will step down, company says. The Washington Post, September 24. Available at: https://www.washingtonpost.com/technology/2019/09/24/weworks-embattled-cofounder-ceo-adam-neumann-will-step-down-company-says/.

Barnard, Chester. 1968. The Functions of the Executive, Harvard University Press, Cambridge: Mass.

Bazerman, Max and Ann Tenbrunsel. 2011. Blind Spots, Princeton University Press.

Becker, G. S. 1968. Crime and Punishment: An Economic Approach. Journal of Political Economy, 76: 169-217.

Beckman, C. M., K. M. Eisenhardt, S. Kotha, A. Meyer, and N. Rajagopalan. 2012. “Technology Entrepreneurship.” Strategic Entrepreneurship Journal, 6: 89-93.

Bengtsson, O., and D. Hsu. 2015. Ethnic Matching in the U . S . Venture Capital Market. Journal of Business Venturing, 30 (2), 338-354.

Bercovici, Jeff. 2017. Here's why Hampton Creek's entire board just quit. Inc. July 10. Available at: https://www.inc.com/jeff-bercovici/hampton-creek-tetrick.html.

Berovici, Jeff. 2019. Silicon Valley CEOs Say You Can Have Either Accountability or Innovation But If Doesn't Have to Be This Way. Inc. Available at: https://www.inc.com/jeff-bercovici/lyft-supervoting-shares-ipo-innovation.html 
Bhattsarai, Abha. 2019. 'Don't game my paycheck': Delivery workers say they're being squeeze by ever-changing algorithms. The Washington Post, November 7. Available at: https://www.washingtonpost.com/business/2019/11/07/dont-gamemy-paycheck-delivery-workers-say-theyre-being-squeezed-by-ever-changingalgorithms/.

Blank, Steve. 2013. Why the Lean Start-Up Changes Everything. Harvard Business Review. May 2013.

Boudette and Ewing 2020. Head of Nikola, a G.M. electric truck partner, quits amid fraud claims, The New York Times, September 21. Available at: https://www.nytimes.com/2020/09/21/business/nikola-trevor-milton-resigns.html.

Brief, A.P., Bertram, R.T., and Dukerich, J. M. (2001), "Collective corruption in the corporate world: Toward a process model”, In Turner, M.E. (Ed.), Groups at Work: Advances in Theory and Research, Lawrence Erlbaum and Associates, Hillsdale, N.J, pp. 471-499

Brodwin, Erin, Ramsey, Lydia, and Court, Emma. 2019. Everything we know about uBiome, the startup that convinced Silicon Valley that testing poop was worth $\$ 600$ million, and then filed for bankruptcy amid an FBI investigation. Business Insider, October 7. Available at: https://www.businessinsider.com/ubiome-whatwe-know-microbiome-startup-fbi-raid-ceos-resigned-2019-7.

Brown, Eliot, Das, Anupreeta, and Farrell, Maureen. 2019. WeWork cleans house, looks to trim staff close to ex-CEO, sell private jet. The Wall Street Journal. October 24. Available at https://www.wsj.com/articles/wework-cleans-house-looks-totrim-staff-close-to-ex-ceo-sell-private-jet-11569531640?mod=e2tw.

Bruton, G. D., Ketchen, D. J., \& Ireland, R. D. 2013. Entrepreneurship as a solution to poverty. Journal of Business Venturing, 28(6): 683-689.

Byers, T. 2020. Entrepreneurship and Ethics. eCorner. Retrieved from https://ecorner.stanford.edu/articles/entrepreneurship-and-ethics/

Cardon, M. S., J. Wincent, J. Singh, and M. Drnovsek. 2009. "The nature and experience of entrepreneurial passion.” Academy of Management Review, 34: 511-532.

Carreyrou, John. 2018. Bad Blood: Secrets and Lies in a Silicon Valley Startup, Knopf, New York.

Cialdini, R. (2001), Influence: Science and Practice. Allyn and Bacon, Boston, MA.

Chatterjee, A. and Pollock, T. 2017: Master of Puppets: How Narcissistic CEOs Construct Their Professional Worlds. Academy of Management Review, 42, 703725.

Chocano, Carina. 2019. Sweet smell of success. The New Yorker. November 4: 26-31. 
Chozick, Amy. 2019. Adam Neumann and the art of failing up. The New York Times, November 2. Available at: https://www.nytimes.com/2019/11/02/business/adamneumann-wework-exit-package.html.

Conger, Kate and Noam Scheiber. 2019. California bill makes app-based companies treat workers as employees. The New York Times, September 11. Available at: https://www.nytimes.com/2019/09/11/technology/california-gig-economybill.html.

Crunchbase. 2020. Crunchbase Diversity Spotlight 2020: Funding to Black \& Latinx Founders. https://about.crunchbase.com/wpcontent/uploads/2020/10/2020 crunchbase diversity report.pdf

DeSantola, A., \& Gulati, R. (2017). Scaling: Organizing and Growth in Entrepreneurial Ventures. Academy of Management Annals, 11(2), 640-668.

Dastin, Jeffery. 2020. Microsoft to divest AnyVision stake, end face recognition investing. Reuters, March 27. Available at: https://www.reuters.com/article/usmicrosoft-anyvision/microsoft-to-divest-anyvision-stake-end-face-recognitioninvesting-idUSKBN21E3BA

Davis, G. F. 2016 The Vanishing American Corporation: Navigating the Hazards of a New Economy. Oakland, CA: Berrett-Koehler Publishers.

Duhigg, Charles. 2020. The enablers, The New Yorker, November 30, pp 38-47.

Eavis, Peter, and Michael J. de la Merced, 2019. WeWork IPO is withdrawn as investors grow wary. The New York Times, September 30. Available at: https://www.nytimes.com/2019/09/30/business/wework-ipo.html.

Eggers, J. P., and L. Song. 2015. "Dealing with failure: Serial entrepreneurs and the costs of changing industries between ventures." Academy of Management Journal, 58: 1785-1803.

Eisenstein, Paul. 2020. Fraud claims, DOJ probe and sexual abuse allegations cloud \$2B deal between GM and Nikola truck startup. NBC News, Sept 30. Available at: https://www.nbcnews.com/business/autos/fraud-claims-doj-probe-sexual-abuseallegations-cloud-2-billion-n1241550.

Fama, E. F. 1980. Agency problems and the theory of the firm. Journal of Political Economy, 88: 288-307.

Fama, E. F. \& Jensen, M. C. 1983. The separation of ownership and control. Journal of Law and Economics, 26: 301-325.

Farrell, Maureen, Liz Hoffman, Eliot Brown, and David Benoit. 2019. The fall of WeWork: How a startup darling came unglued. The Wall Street Journal. October 24. Available at: https://www.wsj.com/articles/the-fall-of-wework-how-a-startupdarling-came-unglued-11571946003. 
Feldman, Daniel, C. 1984. The Development and Enforcement of Group Norms, The Academy of Management Review, Vol. 9, No. 1:47-53.

Fauchart, E., and M. Gruber. 2011. "Darwinians, communitarians, and missionaries: The role of founder identity in entrepreneurship." Academy of Management Journal, 54: 935-957.

Foldy, Ben, Colias, Mike, and Naughton, Nora. 2020. Long Before Nikola Trucks, Trevor Milton Sold Investors on Startups That Faded, The Wall Street Journal, October 1. Available at: https://www.wsj.com/articles/nikola-electric-hydrogentrucks-trevor-milton-11601575695.

Fowler, S. 2020. Whistleblower: My Jpurney to Silicon Valley and Fight for Justice at Uber. Penguin Publishing Group.

First Round, 2019. "State of Startups," Available at: https://stateofstartups2019.firstround.com.

Gabbioneta, Claudia, Greenwood, Royston, Mazzola, Pietro, Minoja, Mario. 2013. The influence of the institutional context on corporate illegality, Accounting, Organizations and Society, Volume 38, Issues 6-7: 484-504.

Garg, S. (2013). Venture Boards: distinctive monitoring and implications for firm performance. The Academy of Management Review, 38(1), 90-108.

Garud, R., H. A. Schildt, and T. K. Lant. 2014. "Entrepreneurial storytelling, future expectations, and the paradox of legitimacy." Organization Science, 25: 14791492.

Garud, R., J. Gehman, and T. Tharchen. 2017. "Performativity as ongoing journeys: Implications for strategy, entrepreneurship, and innovation.” Long Range Planning, 1-10. Elsevier Ltd.

Giorgi, S., C Lockwood and M. A. Glynn. 2015. "The Many Faces of Culture: Making Sense of 30 Years of Research on Culture in Organizational Studies." The Academy of Management Annals 9(1):1-54.

Gluckman, Nell. 2019. Hype vs reality at the MIT Media Lab. The Chronicle of Higher Education, September 20: pp. A10-15.

Graffin, S.D., Bundy, J., Porac, J.F., Wade, J.B., and Quinn, D.P. 2013. Falls from grace and the hazards of high status: The 2009 British MP expense scandal and its impact on Parliamentary elites, Administrative Science Quarterly, Vol. 58, No. 3: 313-345.

Greve, H. R., Palmer, D., Pozner, J-E. 2010. Organizations gone wild: The causes, processes, and consequences of organizational wrongdoing. The Academy of Management Annals, 4 (1): 53-108. 
Grimes, M. 2018. The Pivot: How Founders Respond to Feedback through Idea and Identity Work. Academy of Management Journal, 61 (5) 1692-1717.

Guler, I. 2007 “Throwing good money after bad? Political and institutional influences on sequential decision making in the venture capital industry." Administrative Science Quarterly, 52: 248-285.

Gumbel, Peter, 2004. "How it all went sour," Time Magazine, November 21. Available at: http://content.time.com/time/magazine/article/0,9171,880285,00.html.

Hensley, Laura, 2020. A Toronto startup folded after a sexual harassment claim. This is the woman who spoke out, Global News, February 13. Available at: https://globalnews.ca/news/6499207/planswell-sexual-harassment-allegations/.

Hill, Kashmir and Krolik, Aaron. 2020. At Talkspace, start-up culture collides with mental health concerns, The New York Times, August 7. Available at: https://www.nytimes.com/2020/08/07/technology/talkspace.html.

Hoffman, R., and C. Yeh. 2018 Blitzscaling: The Lightning-Fast Path to Building Massively Valuable Companies. Currency.

hooks, bell. 2004. The Will to Change: Men, Masculinity and Love. Washington Square Press.

Huang, L., and A. P. Knight 2017 "Resources and relationships in entrepreneurship: An exchange theory of the development and effects of the entrepreneur-investor relationship." Academy of Management Review, 42: 80-102.

Huang L., and Pearce, J. 2015. Managing the Unknowable: The Effectiveness of Earlystage Investor Gut Feel in Entrepreneurial Investment Decisions. Administrative Science Quarterly, 60: 634-670.

Huang, L. 2018. The Role of Investors Gut Feel in Managing Complexity and Extreme Risk. Academy of Management Journal, 61 (5): 1827-1847.

Hsu, D. H. 2008 “Technology-Based Entrepreneurship.” In S. Shane (ed.), Handbook of Technology and Innovation Management: 367-388. John Wiley \& Sons Ltd.

Janis I. L. (1971), “Groupthink,” Psychology Today, November, Vol. 5, 43-84.

Janis I. L. (1972), Victims of Groupthink, Boston. Houghton Mifflin Company.

Joint Venture 2020. 2020 Silicon Valley Index.

Jones, T. M., Donaldson, T., Freeman, R. E., Harrison, J. S., Leana, C. R., et al. 2016. Management Theory and Social Welfare: Contributions and Challenges. Academy of Management Review, 41(2): 216-228.

Keltner, D., Gruenfeld, D.H., and Anderson, C. (2003), "Power, approach, and inhibition", Psychological Review, Vol. 110, pp. 265-284. 
Khatchadourian, Raffi. 2019. The burn list. The New Yorker. November 4: 42-57.

Korosec, Kirsten. 2020. Nikola disputes fraud claims in carefully worded rebuttal. TechCrunch, September 14. Available at: https://techcrunch.com/2020/09/14/nikola-disputes-fraud-claims-in-carefullyworded-rebuttal/

Krawiec, Kimberly. 2005. Organizational misconduct: Beyond the principal-agent model. Florida State University Law Review, Vol. 32, No. 2: 571- 625.

Kulik, B. W. (2005), "Agency theory, reasoning and culture at Enron: In search of a solution”, Journal of Business Ethics, Vol. 59, Num. 4, pp. 347-360.

Laursen, Lucas. 2018. 'I Will Not Be a Part of the Charade Anymore.' Why a Facebook Millionaire and Tech Investor Is Getting Out of the Startup 'Ponzi Scheme,' Fortune Magazine, October 11. Available at: https://fortune.com/2018/10/11/social-capitalstartup-growth-ponzi-scheme/.

Lovelace, J., Bundy, J., Hambrick, D., and Pollock, T. 2018: The Shackles of CEO Celebrity: Sociocognitive and Behavioral Role Constraints on "Star" Leaders. Academy of Management Review, 43, 419-444

Lutz, Eric. 2019. WeWork's problems are about to get even worse, Vanity Fair, November 19. Available at: https://www.vanityfair.com/news/2019/11/weworkproblems-are-about-to-get-even-worse-new-york-attorney-general.

McKendall, Marie, A. and Wagner, J. 1997. Motive, Opportunity, Choice, and Corporate Illegality, Organization Science, Vol. 8, No. 6: 624-647

McGregor, Jena. 2019. Adam Neumann's billion-dollar exit package from WeWork is a lesson in giving founders too much control. The Washington Post, October 24. Available at: https:/www.washingtonpost.com/business/2019/10/24/adamneumanns-billion-dollar-exit-package-wework-is-lesson-giving-founders-too$\underline{\text { much-control/. }}$.

Milgram, S. (1963). Behavioral study of obedience, Journal of Abnormal and Social Psychology, Vol. 67, pp. 371-378.

Mische, A. 2009. "Projects and possibilities: Researching futures in action." Sociological Forum, 24: 694-704.

Molla, Rani. 2019. Why WeWork founder Adam Neumann is getting \$1.7 billion to leave the company he ran into the ground. Vox, October 22. Available at: https://www.vox.com/recode/2019/10/22/20927188/wework-adam-neumannpayout-softbank-layoffs.

Monica Gamez-Djokic, Maryam Kouchaki and Adam Waytz. 2021. Virtuous Startups: The Credentialing Power of the Startup Label, Academy of Management Discoveries, forthcoming. 
Nan, Hua. 2019. Roadstar.ai: A promising autonomous driving startup wrecked by infighting, COMPASSLIST, July 25. Available at: https://www.compasslist.com/insights/roadstarai-a-promising-autonomousdriving-startup-wrecked-by-infighting.

Palmer, D. (2008), "Extending the process model of collective organizational wrongdoing," Research in Organizational Behavior, Vol. 28, pp. 107-135.

Palmer, D. 2013. Normal Organizational Wrongdoing, Oxford; Oxford University Press.

Palmer, D., \& Yenkey, C. (2015). Drugs, Sweat and Gears: An Organizational Analysis of Performance Enhancing Drug Use in the 2010 Tour de France. Social Forces.

Palmer, Donald and Valerie Feldman. 2017. "Toward a More Comprehensive Analysis of the Role of Organizational Culture in Child Sexual Abuse in Institutional Contexts." Child Abuse \& Neglect.

Pitchbook 2021. The US VC Female Founders Dashboard. https://pitchbook.com/news/articles/the-vc-female-founders-dashboard Accessed 29 January 2021.

Powell, E. E., and T. Baker. 2014. "It's what you make of it: Founder identity and enacting strategic responses to adversity." Academy of Management Journal, 57: 1406-1433.

Pugh, D. S., Hickson, D. J., Hinings, C. R. and Turner, C., 1969. "The Context of Organization Structures," Administrative Science Quarterly, Vol. 14, No. 1 (Mar., 1969), pp. 91-114.

Rahman H. 2018. Invisible cages: algorithmic evaluations in online labor markets. $\mathrm{PhD}$ Diss., Stanford Univ., Stanford,

Ramey, Corinne. 2021. "Nikola founder Trevor Milton charges with securities fraud," The Wall Street Journal, July 29. Available at: https://www.wsj.com/articles/nikola-founder-trevor-milton-charged-with-lyingto-investors-11627563648.

Ramsey, Lydia. 2019. The mysterious story of former Theranos president Sunny Balwani, who was in a relationship with Elizabeth Holmes and now faces criminal charges, Business Insider, March 19. Available at: https://www.businessinsider.com/theranos-former-president-sunny-balwani-rolein-the-company-2018-5

Reuters. 2019. WeWork faces U.S. SEC inquiry over possible rule violations: Bloomberg, Reuters. November 15. Available at: https://www.reuters.com/article/us-wework-sec/wework-faces-u-s-sec-inquiryover-possible-rule-violations-bloomberg-idUSKBN1XP1YE. 
Ries, Eric (2011). The Lean Startup: How Constant Innovation Creates Radically Successful Businesses. Portfolio Penguin.

Rivera, L. 2012. "Hiring as Cultural Matching: The Case of Elite Professional Service Firms." American Sociological Review, 77: 999-1022.

Roethlisberger, F.J. and William J. Dickson, 1947. Management and the Worker, Harvard University Press, Cambridge: Mass.

Rosenfeld, Seth. 2020. California agency is hiding Uber and Lyft accident reports. San Francisco Public Press, January 7. Available at: https://sfpublicpress.org/news/2020-01/california-agency-is-hiding-uber-and-lyftaccident-reports.

Rouse, E. D. 2016. "Beginning's end: How founders psychologically disengage from their organizations." Academy of Management Journal, 59: 1605-1629.

Roy, Donald. 1957. Banana time: Job satisfaction and informal interaction. Human Organization. 18 (4): 158- 168.

Ruef, M., H. Aldrich, and N. Carter. 2003."The structure of founding teams: Homophily, strong ties, and isolation among US entrepreneurs." American Sociological Review, 68: 195-222.

Salancik, G. and Pfeffer, J. 1977. Who gets power and how they hold on to It: A strategic contingency model of power, Organizational Dynamics, Vol. Winter, pp. 3-21.

Savoia, Alberto. 2019. The Right It: Why Do many Ideas Fail and How to Make Sure Yours Succeed. HarperOne.

Scheaf, D. J. and Wood, M. S. (2021) 'Entrepreneurial Fraud: A Multidisciplinary Review and Synthesized Framework', Entrepreneurship Theory and Practice. doi: $\underline{10.1177 / 10422587211001818 .}$.

Scott, Richard. 2013. Institutions and Organizations. Sage Publications: Los Angeles, CA.

Shaw, M. Group dynamics. 3rd ed. New York: Harper, 1936.

Shepherd, D., Patzelt, H., \& Baron, R. 2012. "I Care about Nature, but ...”: Disengaging Values in Assessing Opportunities that Cause Harm. Academy of Management Journal, 56 (5): 1251-1273.

Shepherd, D. A. 2019. "Researching the Dark Side, Downside, and Destructive Side of Entrepreneurship: It is the Compassionate Thing to Do!" Academy of Management Discoveries, 5: 217-220. 
Siddiqui, Faiz. 2019/ Uber discloses 3,000 reports of sexual assault on U.S. rides last year in its long-awaited safety study. The Washington Post. December 5. Available at: https://www.washingtonpost.com/technology/2019/12/05/uber-disclosed-sexualassaults-us-rides-last-year-its-long-awaited-safety-report/?arc404=true.

Sine, W. D., Mitsuhashi, H., \& Kirsch, D. A. (2006). Revisiting Burns And Stalker: Formal Structure And New Venture Performance In Emerging Economic Sectors. Academy of Management Journal, 49(1), 121-132.

Simpson, S. S. 1986. The decomposition of antitrust: Testing a multilevel, longitudinal model of profit-squeeze", American Sociological Review, Vol. 51, pp. 859-975.

Sims, R. R. and Brinkmann, J. (2003), "Enron ethics (Or: Culture matters more than codes)", Journal of Business Ethics, Vol. 45, Num. 3, pp. 243-256.

Soltys, Douglas. 2019. Planswell CEO attributes company downfall to "social media storm" in investor email. Betakit: Canadian Startup News and Tech Innocation, November 5. Available at: https://betakit.com/planswell-ceo-attributes-companydownfall-to-social-media-storm-in-investor-email/

Song, Lisa, and Larkin, Max. 2019. MIT Media Lab kept regulators in the dark, dumped chemicals in excess of legal limit. ProPublica, September 20. Available at: https://www.propublica.org/article/mit-media-lab-kept-regulators-in-the-darkdumped-chemicals-in-excess-of-legal-limit.

Spilling the Blood of a Silicon Valley Unicorn. 2019. YouTube Video, added by Ethics in Society. Available at https://www.youtube.com/watch?v=YJXcU9CKLI\&feature $=$ emb_logo

Staw, B. M. (1976), "Knee-deep in the big muddy: A study of escalating commitment to a chosen course of action", Organizational Behavior and Human Performance, Vol. 16, pp. 27-44.

Staw, B. M. and Szwajkowski, E. (1975), The scarcity-munificence component of organizational environments and the commission of illegal acts, Administrative Science Quarterly, Vol. 20, pp. 345-354.

Stephen, B. 2018. "The Gospel of Elon Musk, According to his Flock." The Verge. Retrieved from https://www.theverge.com/2018/6/26/17505744/elon-musk-fanstesla-spacex-fandom.

Stoller, Matt. 2019. WeWork and counterfeit capitalism. Big, September 25. Available at: https://mattstoller.substack.com/p/wework-and-counterfeit-capitalism.

Sykes, G. and Matza, D. (1957), Techniques of neutralization: A theory of delinquency, American Sociological Review, Vol. 22:6, pp. 664-670. 
The Inventor: Out for Blood in Silicon Valley (2019), Alex Gibney, HBO, Film.

Timmons, Heather and Bettina Wassener 2009. "Satyam chief admits huge fraud," The New York Times, January 7.

Trivino, Linda K. and Nelson, Katherine A. 2017. Managing Business Ethics: Straight Talk about How to Do It Right, Hoboken: Wiley.

U.S. Securities and Exchange Commission, 2018. Elon Musk settles SEC fraud charges; Tesla charged with and resolves securities law charge. Press Release 2918-226. Available at: https://www.sec.gov/news/press-release/2018-226.

Vallas, Steven and Schor, Juliet. 2020. What do platforms do? Understanding the gig economy. Annual Review of Sociology, Vol. 46: 273-294.

Valukas, Anton R. "Report to Board of Directors of General Motors Company Regarding Ignition Switch Recalls, May29, 2014,” Jenner \& Block, select pages. Available at: http://www.beasleyallen.com/webfiles/valukas-report-on-gm-redacted.pdf.

Zhao, E. Y., \& Wry, T. 2016. Not all inequality is equal: Decomposing the societal logic of patriarchy to understand microfinance lending to women. Academy of Management Journal, 59(6): amj.2015.0476.

Wainstein, Kenneth, A. Joseph Jay III, and Colleen Depman Kukowski, (2014) "Investigation of Irregular Classes in the Departmennt of African and AfroAmerican Studies at the University of North Carolina at Chapel Hill", Cadwalader.

Watt, P. 2016 “The rise of the 'dropout entrepreneur': dropping out, 'self-reliance' and the American myth of entrepreneurial success." Culture and Organization, 22: 2043.

Wasserman, N. 2012. The founder's dilemmas: Anticipating and avoiding the pitfalls that can sink a startup. Princeton University Press.

Weber, Max.1922/1978, Economy and Society. Berkeley: University of California Press.

Welter, F., T. Baker, D. B. Audretsch, and W. B. Gartner. 2017. "Everyday Entrepreneurship - A Call for Entrepreneurship Research to Embrace Entrepreneurial Diversity.” Entrepreneurship: Theory and Practice, 41: 311-321.

Wood, M.; Bakker, R.; and Fisher, G. (2021). Back to the Future: A Time-calibrated Theory of Entrepreneurial Action. Academy of Management Review.

Zaleski, Olivia, Waldman, Peter, and Huet, Ellen. 2016. How Hampton Creek sold Silicon Valley on a fake-mayo miracle. Bloomberg Businessweek, September 22. Available at: https://www.bloomberg.com/features/2016-hampton-creek-justmayo/. 
Zuboff S. 2019. The Age ofSurveillance Capitalism. New York: Public Aff.

Zuckerman, E. 2017 “Zuckerberg and the Imaginary Cosmopolitan." The California Review of Images and Mark Zuckerberg, Winter. 